\title{
The Criteria to Qualify a Geographical Term as Generic: Are We Moving from a European to a US Perspective?
}

\author{
Alberto Ribeiro de Almeida (iD) Suelen Carls $\mathbb{D}$
}

Accepted: 22 February 2021 / Published online: 16 March 2021

(C) The Author(s) 2021

\begin{abstract}
This article discusses the transformation of a distinctive trade sign into a generic term. Any distinctive trade sign carries this risk, primarily if it benefits from a high level of reputation or prestige, and the product identified is unique in the market. This is probably the most critical danger for such signs, especially if they are industrial property rights. Several criteria have been developed to determine if a sign has been transformed into a generic term. These criteria have economic and political relevance, as genericness is not a trivial issue. The European Court of Justice (ECJ) has taken a position in this matter, as have the European Union Regulations on trademarks and geographical indications. However, the bilateral and multilateral agreements are the critical arena for conflicts concerning geographical terms' qualification as common terms. The European Union (EU) and the United States (US) have been in the spotlight for a long time, while China is also reaching a prominent place in this dispute. The most recent bilateral agreements have been twisting the criteria applied when assessing a geographical term's genericness.
\end{abstract}

Keywords Geographical indications · Genericness · European Union · United States $\cdot$ China $\cdot$ Free trade agreements

Both co-authors may be regarded as corresponding authors and are equally responsible for the article.

\footnotetext{
A. R. de Almeida $(\bowtie)$

Dr.; Professor of Law, Lusíada University - North, Porto, Portugal

e-mail: afribeirodealmeida@gmail.com

S. Carls $(\bowtie)$

Dr.; Senior Research Fellow, Max Planck Institute for Innovation and Competition, Munich, Germany

e-mail: suelen.carls@ip.mpg.de
} 


\section{Introduction}

To be recognised as an industrial property right a trade sign must comply with its legal function, namely distinctiveness. Generic terms cannot be an object of ownership (they are res communes omnium) as they do not comply with the function of distinctiveness. A watchmaking company that wishes to distinguish its watches in the market from other watches produced by its competitors cannot be the owner of the sign watch as a trademark because this sign is generic: it is the name of the product and thus cannot distinguish the company's products from similar products produced by its competitors. The legal function of distinctiveness must be the legal ground for recognising a sign as a trademark or denying that recognition because the sign has lost its distinctiveness and can no longer distinguish the products in the market concerning their business origin. The problem relies on the criteria applied to declare a sign distinctive or generic, and the moment to do so.

The same reasoning must be used for geographical indications (GIs) and designations of origin (DOs). These industrial property rights comply with two different legal functions: a geographical indication function and a quality function. At least for DOs it is clear that they comply with these two legal functions but for some GIs, based only on reputation, we are probably only facing a GI function. This means that a sign may be protected as a GI or a DO if it has distinctiveness, i.e. it can distinguish a product from a specific geographical origin (and a certain quality) from similar products produced by other companies and coming from other geographical origins (and with different quality). ${ }^{1}$ If cheese is a generic term, is Edam a generic term? We must distinguish generic terms (the name of the product) from descriptive terms (for example, indicating characteristics like blue cheese or goat cheese) and from common or usual terms in the market. ${ }^{2}$ A generic term does not intrinsically convey a message of distinction, i.e. it is not able to accomplish the distinctiveness function; the descriptive terms and the common or usual terms are not able to distinguish the products in the market because those terms must be left free (the Freihaltebedürnis doctrine ${ }^{3}$ ) for all competitors on behalf of the general interest. ${ }^{4}$ The capacity to distinguish, however, changes over time: it may be lost or may be acquired. ${ }^{5}$

The genericness, descriptiveness or commonness of a given term should be based on the same criteria, and it does not depend on when the assessment is performed,

\footnotetext{
${ }^{1}$ In this respect, Kur and Cocks (2007), p. 1005, affirm that: "correct and complete indications of geographical origin on products benefit both producers and consumers, particularly when such indications convey a sense of the unique qualities that the region from which a product originates imparts on the product, as is typically the case with foodstuffs and other agricultural products".

2 Fletcher (2013), p. 501, says "the best definition of generic name is 'the name of a thing' with 'thing' meaning 'an object of concern' in the sense of attention, not worry" and, to distinguish generic, descriptive, suggestive and arbitrary or fanciful "we can probably all agree that 'car' is generic and 'fast' is descriptive".

3 See Fezer (2009), p. 673.

4 See Massimo and Fransozi (2014), p. 152; Vanzetti (2013), p. 211.

5 See Ghidini and Cavani (2014), p. 68; Vanzetti and Di Cataldo (2012), p. 287; Massimo and Fransozi (2014), p. 157.
} 
whether before or after registration. In any case, we are evaluating the distinctiveness of the sign (the ability of the sign to accomplish certain legal functions), but the extinction of an industrial property right over a sign has severe consequences for that right's owner; more severe than the refusal of registration or protection of the sign as a DO or GI. This is especially true if the extinction of the right owing to genericness is a consequence of the success in the market of the sign protected as a DO or GI (a success due to the owner's activities: promotion, publicity, high quality of the product, and the prestigious image of the sign, for instance). This means that genericness must be evaluated with caution and safety criteria, without any hesitation.

The qualification of a DO or GI as a generic term demands the breakdown of both the geographic-qualitative link (a link of truth) and the ideographic connection (a distinctive power) with a particular geographical origin. This paper aims to bring those issues together and offer an analysis of how, or if, the bilateral and multilateral agreements influence the genericness assessment and whether they had an impact on it or are about to have an impact.

Then come the questions: is there a move from the European Union perspective to the United States perspective concerning the genericness assessment? Will the US-China agreement be a reference point? By analysing the available literature, regulations and the texts of bilateral and multilateral agreements, as well as the ECJ case law, this paper will attempt to answer those questions, in a context where the existence of a subjective industrial property right is at stake. The work undertaken to address the questions in this article features six sections, starting with this introduction. Sect. 2 deals with the European Union framework, presenting the relevant regulations and case law. Next, Sect. 3 analyses the implications of free trade agreements in the European framework. Sect. 4 presents the criteria used both by Europe and the US when assessing a geographical name's genericness. Finally, Sect. 5 considers the possibilities of the survival and revival of generic terms. Section 6 closes the article with the author's conclusions.

\section{European Union Legal Framework}

A name becomes generic when it does not convey its original meaning anymore, i.e. when consumers no longer perceive the name as an indication of a given product's specific geographical origin and its specificities. For instance, when the name can be understood only as a kind or a product category in such a case. In other words, when it has lost its distinctiveness.

Following logical thinking and the rules on distinctive signs, if a name has become generic, it no longer deserves protection as a distinctive sign because its essential feature is absent. There is, however, not merely one solution to deal with cases of genericness. Although the US and the EU are the protagonists, there is room for nuances and China is playing an interesting role in this regard 
Neither the Paris Convention of 1883, nor the Madrid Agreement of 1891, nor the Lisbon Agreement of 1958 dealt objectively with genericness. ${ }^{6}$ The much more recent TRIPS Agreement does not provide a clear guideline either, as it only formalises the rule by which the members are not obliged to offer GI protection in case a given indication refers to a term that is customary in common language as a common name for specific goods or services (e.g. china for porcelain). ${ }^{7}$ However, it is as abstract as we would expect from an international set of rules, which intends to establish minimum standards.

As general as it is, the European legislation on GIs complied with the TRIPS guideline even before 1994, within its quality schemes regulation. Council Regulation 2081/92, ${ }^{8}$ for instance, already provided directions related to: the impossibility of registration of a name that had become generic; what was to be considered as a generic name; genericness as a valid argument for objection; and the impossibility of a registered name becoming generic.

Regarding agri-foodstuff GIs, from the 1992 Regulation onwards, the topic of genericness never left the table. Council Regulation (EC) No 510/2006 ${ }^{9}$ brought the same provisions, which were then transplanted into Regulation (EU) No 1151/2012 currently in force. Similar provisions are also part of the regulations for wines, spirits and aromatised wines.

The currently most mentioned and well-known Regulation when we talk about GIs and DOs is Regulation (EU) No 1151/2012 on agricultural products and foodstuffs. After some considerations given in the preamble, ${ }^{10}$ it defines what constitutes a generic term. ${ }^{11}$ Then comes the prohibition of registration of a generic term as a protected designation of origin or a geographical indication. ${ }^{12}$ Moreover, genericness is considered a valid ground for opposition. ${ }^{13}$ It also clarifies that using a generic term that is part of a protected designation of origin or a protected geographical indication does not constitute a violation. Finally, the Regulation enumerates the main factors to be considered in order to verify whether a name has become generic or not. ${ }^{14}$

\footnotetext{
${ }^{6}$ Gangjee (2012).

7 See Art. 24(6) Agreement on Trade-Related Aspects of Intellectual Property Rights: “(...) to goods or services for which the relevant indication is identical with the term customary in common language as the common name for such goods or services in the territory of that Member".

8 See Arts. 3(1) and (3); 4; 13(1)(d) and (3); and Art. 17(2) Council Regulation (EEC) No 2081/92 of 14 July 1992 on the protection of geographical indications and designations of origin for agricultural products and foodstuffs.

9 See Council Regulation (EC) No 510/2006 of 20 March 2006 on the protection of geographical indications and designations of origin for agricultural products and foodstuffs.

10 See numbers 52 and 63 in the Preamble to Regulation (EU) No 1151/2012 of the European Parliament and of the Council of 21 November 2012 on quality schemes for agricultural products and foodstuffs.

11 See Art. 3(6) ibid.: "means the names of products which, although relating to the place, region or country where the product was originally produced or marketed, have become the common name of a product in the Union".

12 See Art. 6(1) ibid.

13 See Art. 10(1)(d) ibid.

14 See Art. 41(2)(a) and (b) ibid.
} 
Furthermore, Regulation (EU) No 1308/2013 dealing with wines provides that neither a protected designation of origin, nor a protected geographical indication, nor traditional terms shall become generic. ${ }^{15}$ In the additional grounds for refusal of protection, the Regulation's definition of a generic term is included. ${ }^{16}$ In the end, the Regulation presents the same main criteria for the establishment of a term as generic or not. ${ }^{17}$

Following those rules, Regulation (EU) $2019 / 787^{18}$ and Regulation (EU) $251 / 2014^{19}$ dealing with aromatised wine products and spirit drinks, respectively, provide the same definitions and rules as we find in the wine or in the foodstuff regulations.

Although only the rules are mentioned above that came after the establishment of the quality schemes under the Common Agriculture Policy (CAP), which dates back to 1992 , the EU already dealt with genericness in the 1970 s.

The records show a coherent link between free movement ${ }^{20}$ and food name rules. In this sense, succeeding Dassonville ${ }^{21}$ in 1974 and Cassis de Dijon ${ }^{22}$ in 1979, the principle of mutual recognition was put in place. It was established as the elementary ground against national standards by the Member States when using specific food names in reference to imported products. Those judgments paved the way for the genericness analysis, as they are the sources from which we can extract the first Court (direct or indirect) opinions on that issue.

To illustrate this relationship, we can mention the $S e k t^{23}$ case. The judgment considered Sekt and Weinbrand as generic in nature as they did not represent indications of origin. ${ }^{24}$ The German government could not justify reserving Sekt and

\footnotetext{
15 See Arts. 103(3) and 113(3) Regulation (EU) No 1308/2013 of the European Parliament and of the Council of 17 December 2013 establishing a common organisation of the markets in agricultural products and repealing Council Regulations (EEC) No 922/72, (EEC) No 234/79, (EC) No 1037/2001.

16 See Art. 101(1) ibid, according to which the "name of a wine which, although it relates to the place or the region where this product was originally produced or marketed, has become the common name of a wine in the Union".

17 See Art. 101(1)(a) and (b) ibid.

18 See Arts. 21(3) and 35(1)(a) and (b) Regulation (EU) 2019/787 of the European Parliament and of the Council of 26 February 2014 on the definition, description, presentation, labelling and the protection of geographical indications of aromatised wine products.

19 See Arts. 18(1)(a) and (b) and 20(3) Regulation (EU) 251/2014 of the European Parliament and of the Council of 17 April 2019 on the definition, description, presentation and labelling of spirit drinks, the use of the names of spirit drinks in the presentation and labelling of other foodstuff.

${ }^{20}$ For general overviews of the case law concerning free movement of food, see Holland and Pope (2004); MacMaoláin (2007).

21 Case C-8/74 - Procureur du Roi v Benot̂t and Gustave Dassonville, Judgment of 1974.

22 Case C-120/78 - Rewe-Zentral AG v Bundesmonopolverwaltung für Branntwein, Judgment of 1979.

23 Case C-12/74 - Commission of the European Communities $v$ the Federal Republic of Germany, Judgment of 1975.

${ }^{24}$ Germany had reserved these names for itself to overcome the free movement rules and quota restrictions in place at the time.
} 
Weinbrand only to German products based on consumer protection and fair competition. $^{25}$

In a more recent and specific case, a company based in Italy produced several different types of cheeses including one that complied with the PDO Parmigiano Reggiano production rules. Another variety produced by the same company was only a mixture of many kinds of cheese with different origins in a powder form, which did not meet the PDO Parmigiano Reggiano production rules. This cheese was, however, labelled as Parmesan and sold around the world, outside Italy. In this case, Germany argued that the designation Parmesan was a generic name and not a PDO according to the meaning provided by Regulation 2081/92. The argument pointed out that the name was generic because it became a name used to refer to hard cheese. Germany added that the name under protection was Parmigiano Reggiano and that the protection was restricted to that form of the name.

The arguments failed, and the ECJ affirmed that it was far from clear or evident that Parmesan had become generic. Germany was the only country among those submitting written observations to the ECJ to argue that Parmesan had become generic. All the others pointed out that Parmesan was a correct translation of Parmigiano Reggiano, meaning that under Art. 13(3) of Regulation 2081/92 the translated name of a registered PDO or PGI is also protected against genericness.

In another Parmigiano Reggiano case, ${ }^{26}$ the European Commission brought a complaint against Germany, because in its understanding Germany had the legal obligation of prosecuting its national producers who were labelling their cheeses like Parmesan. The reason was that Parmesan was a translation of the PDO Parmigiano Reggiano and the use of that expression violated the protected PDO. The German government, in turn, refused to act. It claimed that, although the term Parmesan had a historical attachment to the Parma region, it was already a generic term used to refer to any hard cheeses of any geographical origin. For this reason, the use of the term by the German producers did not infringe the PDO Parmigiano Reggiano and the EU Regulation in force (1992).

The ECJ confirmed its previous understanding of the Parmigiano Reggiano issue. However, the Court concentrated its analysis not on the translation argument, but considered Parmesan an evocation of the PDO Parmigiano Reggiano. Still, the German arguments stating that Parmesan constituted a generic name were incidentally disregarded in Court. ${ }^{27,28}$ To justify the decision, the ECJ considered: (a) the places where the product production was present; (b) the product's consumption and the consumer's perception; (c) the existence of domestic legislation for the product; and (d) how the name has been presented in EU law.

\footnotetext{
25 The same was ruled in Case C-325/00 - Commission of the European Communities v Federal Republic of Germany, Judgment of 2002.

26 C-132/05 - Commission of the European Communities v Federal Republic of Germany, Judgment of 2008.

27 See ibid., paras. 49-50.

28 On a sidenote, it is interesting to note that the Commission had accepted that PDOs could become generic (referring to Camembert and Brie).
} 
The final solution was a win for the Italian PDO producers. However, concerning the initial EU Commission complaint against the German authorities' inaction, the judges declared that Germany was not obliged to protect the PDO Parmigiano Reggiano under EU law. This task was to be done by Italy. ${ }^{29}$

The Feta case is, however, one of the most emblematic (and controversial) cases related to genericness. If Feta, for most people, refers to a cheese produced in Greece, it is at the same time a non-geographical name. ${ }^{30}$ Feta was registered as a PDO at EU level in 1996. Three years later, though, after being challenged by Denmark, Germany and France, ${ }^{31}$ the protection was revoked. They argued that Feta had a generic nature, and, as happens to trademarks, no protection should be given as a PDO or a PGI if there is an interest of the Member States to use the term freely. The Commission took a position in the matter and performed a survey to allow the Member States to understand Feta's genericness. In the end, a conclusion was reached in the sense that Feta was not generic. Protection was then restored. ${ }^{32}$

Because in Denmark (since 1963) and Germany (since 1985) the use of Feta by national producers was permitted, they tried to reverse the decision, but failed. ${ }^{33}$ The arguments were rejected again. The ECJ also highlighted that, although Feta does not refer to a geographical place, it is a non-geographical name according to the provisions of the relevant Regulation and it designates a specific product, which originates from a specific place.

Another relevant case for this discussion, which involves trademark issues, concerns Grana Padano cheese. ${ }^{34}$ In 1999, the Office for Harmonisation in the Internal Market (OHIM) registered the Community trademark ${ }^{35}$ Grana Biraghi for various kinds of cheese produced in Italy. Nearly three months later, the Consorzio per la Tutela del Formaggio Grana Padano applied for and obtained a declaration of cancellation $^{36}$ of the OHIM trademark.

In response, Biraghi appealed and the understanding of the topic changed. The First Board of Appeal of OHIM believed that the word "grana" was generic and descriptive so that the existence of the PDO Grana Padano did not influence the registration of the trademark Grana Biraghi. The Grana Padano producers went to the Court of First Instance of the European Communities to annul that decision. The

\footnotetext{
${ }^{29}$ Other interesting findings of the case include the affirmation of a conceptual proximity as well as phonetic and visual similarities that, in the way they were established, easily brought the PDO-protected Parmigiano Reggiano to the consumer's mind. Therefore, the use of the term Parmesan led to evocation of the real product. And the fact that the word in use is a translation does not change the interpretation given to the case.

${ }^{30}$ Feta comes from the Italian fette, referring to a slice of food. Byrne (2006), p. 366.

31 Joined cases C-289/96, C-293/96 and C-299/9 - Kingdom of Denmark, Federal Republic of Germany and French Republic v Commission of the European Communities, Judgment of 1996.

32 Denmark and France, however, did not accept and tried to reverse the decision, but they failed.

33 See Knaak (2015).

34 Case T-291/03 - Consorzio per la tutela del formaggio Grana Padano v OHMI - Biraghi (GRANA BIRAGHI), Judgment of 2007.

35 Council Regulation (EC) No 40/94 of 20 December 1993 on the Community trade mark.

36 Against the registration of the earlier, national and international marks, GRANA and GRANA PADANO and infringement of the designation of origin Grana Padano.
} 
trademark registration was annulled, and the Court held that Grana was not a generic name and that the existence of the PDO Grana Padano precluded the Grana Biraghi registration.

\section{Impact of International Agreements in the European Legal Framework}

In recent years, much has changed regarding determining that a term is generic in several international agreements. We will consider the most relevant bilateral agreements and multilateral agreements, especially on their significance for the EU perspective on this issue.

The Economic and Trade Agreement between the Government of the United States of America and the Government of the People's Republic of China has several rules on generic terms in the chapter on geographical indications (section F). An objective perspective (US perspective) was taken. Firstly, the agreement is explicit in qualifying as equivalent generic terms and common terms or a term customary in common language as a common name. Secondly, GI protection and recognition in China by any other trading partner "do not undermine market access for US exports to China of goods and services using trademarks and generic terms" (Art. 1(15)(1)). This provision undermines GI protection in China (a product identified with a generic term in the US can be sold in China even if it conflicts with a protected GI) and infringes basic industrial property principles like the territoriality principle. ${ }^{37}$ Thirdly, Art. 16(1)(b) allows the subsequent genericness of a GI ("any geographical indication, whether granted or recognised pursuant to an international agreement or otherwise, may become generic over time, and may be subject to cancellation on that basis"). The EU has a different perspective, ${ }^{38}$ but this Article will allow an EU GI that is protected in China to be subsequently considered generic, and the registration will be cancelled. Finally, in Art. 16(1), the US-China agreement establishes the criteria for considering a term as generic in China. That is, "how consumers understand the term in China" considering: (a) "competent sources such as dictionaries, newspapers, and relevant websites"; (b) how the good is "marketed and used in trade in China"; (c) how the term is used in relevant standards to refer to a type or class of goods in China, such as according to a standard promulgated by the Codex Alimentarius; and (d) "whether the good in question is imported into China, in significant quantities, from a place other than the territory identified in the application or petition, and in a way that will not mislead the public about its place of origin, and whether the term names those imported goods". This means that the agreement only considers the consumer understanding of the term and the trade opinion (based on objective criteria); there is no consideration of the owner's behaviour concerning the GI. It will be easy for a

\footnotetext{
37 A basic principle of the Paris Convention for the Protection of Industrial Property and of the TRIPS Agreement.

${ }^{38}$ It is relevant to underline that in the EU and in most of the bilateral agreements concluded by the EU with third countries it is expressly established that a protected GI cannot become generic. However, in the agreement between the EU and China this provision was not included.
} 
protected GI to become generic in China. The only reassurance for GI owners is that a GI considered generic in the US is not automatically generic in China.

The agreement between the European Union and the government of the People's Republic of China on cooperation on, and protection of, geographical indications does not have rules on generic terms, which means that a Chinese GI protected in the EU cannot become generic in the EU. However, an EU GI that is protected in China can become generic in China. Paradoxically, it is established in Art. $2(1)(\mathrm{g})$ that there will be "an opposition procedure that allows the legitimate interests of prior users of names, whether those names are protected as a form of intellectual property or not, to be taken into account". This means that prior use of GIs as generic/common terms will have to be considered in order to decide if they can be protected in China or not. The criteria are those of Chinese law, which are different from the EU criteria.

The EU-Mercosur trade agreement, concerning GIs (in the chapter on intellectual property), has rules on generic terms. Article 35(10) states that protected geographical indications shall not become generic in the territories of the parties. This is the main rule. However, it is also foreseen that a GI protected in a contracting party may not be protected in another contracting party because the term (identical to the $\mathrm{GI}^{39}$ ) is considered a common name of the goods concerned in the territory of this party (Art. 35(6)). Nevertheless, the agreement does not establish the criteria to consider a GI generic in another contracting party - it will be the national rules that decide if the term is generic or not.

The new US-Mexico-Canada Agreement (USMCA) replaces the North American Free Trade Agreement (NAFTA) and contains rules on generic terms concerning GIs. In the first place, the agreement establishes (chapter 20, Art. $20(31)^{40}$ ) that protection or recognition of a GI may be denied, opposed and cancelled, namely on the ground that the GI is considered "a term customary in common language as the common name for the relevant good in the territory of the Party". Secondly, Art. 20(32) establishes guidelines for determining whether a term is customary in common language as the common name for the relevant good in a party's territory.

The territoriality principle applies, but the national authorities of the parties must consider the consumer's understanding of the term according to the following objective criteria: (a) whether the term is used to refer to the type of good in question (that is, it does not indicate the geographical origin or quality, but a type of product), as indicated by competent sources such as dictionaries, newspapers, and relevant websites; (b) how the good referenced by the term is marketed and used in trade (opinion of the trade); (c) "whether the term is used, as appropriate, in relevant international standards recognised by the Parties to refer to a type or class of good in

\footnotetext{
39 It also includes, according to Art. 35(7), a translation of a geographical indication that "is identical with or contains within it a term customary in common language as the common name for a product in the territory of a Party, or if a geographical indication is not identical with but contains within it such a term, the provisions of this Sub-Section shall not prejudice the right of any person to use that term in association with that product".

40 However, "a Party is not required to apply this Article to geographical indications for wines and spirits or to applications or petitions for those geographical indications".
} 
the territory of the Party, such as pursuant to a standard promulgated by the Codex Alimentarius"; and (d) "whether the good in question is imported into the Party's territory, in significant quantities, from a place other than the territory identified in the application or petition, and whether those imported goods are named by the term".

No consideration is made regarding the action or inaction of the GI's owner. Subjective criteria are not considered. Thirdly, the agreement foresees something new: an extraterritorial effect. Article 20(35) determines that if a party to the USMCA protects or recognises a geographical indication according to an international agreement (especially with a third party), according to footnote 25 of the USMCA, it must apply the guidelines for determining whether a term is the term customary in common language (Art. 20(32)) in deciding whether to grant protection or recognition of a geographical indication of that third party. If Mexico concludes a bilateral agreement with, for example, the EU or Brazil it must apply the criteria for genericness of the USMCA. It must also foresee that the protection or recognition of a geographical indication can cease or be cancelled. ${ }^{41}$ This is an extraterritorial effect of the USMCA imposed on the parties to this agreement.

The most recent agreement relevant for this issue is the Regional Comprehensive Economic Partnership (RCEP) agreement. ${ }^{42}$ Chapter 11 , section D, contains rules on GIs. Firstly, it is possible to oppose, refuse and cancel the protection of a GI (Art. $11(30)(2),(31)(1)$ and (31)(3)) based on the ground that the GI "is a term customary in common language as the common name for the relevant good in the territory" of a party. Common names include generic terms. Secondly, Art. 11(31)(3) establishes the criteria for determining whether a term is "a term customary in common language as the common name for the relevant good in the territory of a Party" (recognition of the territoriality principle). Considering the common language of the consumer's understanding of the term, the competent authorities (of the party) shall apply the following factors to determine the consumer understanding: (a) use of the term as indicating a type of product by dictionaries, newspapers, and relevant websites; (b) how the good referenced by the term is marketed and used in trade; and (c) whether the term is used in relevant international standards to refer to a type or class of goods. Thus, consumer opinion and the trade opinion, according to objective criteria, are decisive for a GI to be considered a generic term and, consequently, the competent authority will refuse or cancel its protection. Thirdly, the agreement has an extraterritorial effect, meaning that if a party protects or recognises a GI under an international agreement involving a party or a non-party, that party shall ensure that those GIs that are being considered for protection or recognition may be opposed on the ground that the GI is a common name.

Concerning the TRIPS Agreement, Art. 24(6) allows a member not to protect a GI from another member if in its territory that indication is "identical with the term customary in common language as the common name" for the goods or services

\footnotetext{
${ }^{41}$ However, there is an exception in Art. 20(35)(4) for GIs identifying wines and spirits.

42 Parties to this agreement are: Australia, Brunei, Cambodia, China, Indonesia, Japan, Laos, Malaysia, Myanmar, New Zealand, the Philippines, Singapore, South Korea, Thailand, and Vietnam.
} 
identified by the GI. ${ }^{43}$ The TRIPS Agreement demands that the term is identical to the GI, and it is difficult to understand the reference to services when the GI definition has not foreseen the possibility of a GI identifying services. ${ }^{44}$ However, more important is the combination of that Article with Art. 24(3). In our opinion, this Article imposes a standstill clause, meaning that a GI that is already (that is before the date of entry into force of the WTO Agreement) protected as such in a WTO member cannot become generic or have its protection diminished in any way. ${ }^{45}$

From the above-referred agreements, we may conclude that we have two different positions in the world on the regulation of genericness: of the US and several Asian countries on one side and the European Union on the other side. The first group adopts the traditional US perspective, which is the objective criterion. The EU follows a subjective criterion, even precluding a GI from becoming generic. ${ }^{46}$ This also means, finally, that the EU has its eyes on the industrial property right as a property right. In contrast, the US and the Asian countries have their eyes on the market. Of course, each sees what is more important for economic and ideological approaches to protect their economic interests - in all the legal rules.

\section{Genericness Assessment Criteria}

The rule that a name has become generic means establishing a broken link between the term and the territory, ${ }^{47}$ which needs to be present to secure intellectual property protection for the GI quality scheme. ${ }^{48}$ The analysis, which can lead to recognition of genericness, may be carried out by considering different factors, such as the consumption and the production particularities of the legal framework. ${ }^{49}$ There are, therefore, diverse approaches when it comes to assessing a name's genericness - or descriptiveness - and they vary mainly from one country to another, which is

\footnotetext{
43 About this Article, see Gangjee (2016), p. 518 et seq.

${ }^{44}$ About this problem, see Gervais (2003), p. 136.

${ }^{45}$ See Correa and Correa (2007), p. 248.

${ }^{46}$ In the doctrine and about this dispute between objective criteria and subjective criteria in the trademark field, see, among others: Mikorey (2001); Frassi (2013); Vanzetti (2009), p. 280; Massimo and Fransozi (2014), p. 294; Liuzzo (1994), p. 881; Briceno Moraia (2000), p. 238; McCarthy (1996), pp. 12-27; Ladas (1975), pp. 617-618, 1168, 1235; McManis (2000), p. 145 et seq. For other references and the comparison between trademarks and GIs, see, in detail, Ribeiro de Almeida (2010), pp. 1155-1225.

${ }^{47}$ See Case C-446/07 - Alberto Severi v Regione Emilia Romagna, Judgment of 2009, para. 51.

${ }^{48}$ Some of the most discussed and analysed cases concerning the generic nature of food names relate to registration of the name Feta. For an overview of the cases, see O'Connor and Kireeva (2003). For general discussions on privatising expressions of the common language, see Jokuti (2009).

49 In Joined cases C-465/02 and C-466/02 - Federal Republic of Germany (C-465/02) and Kingdom of Denmark (C-466/02) v Commission of the European Communities, Judgment of 2005, the Court assessed the generic character of the name Feta by examining: (a) the production situation inside and outside Greece; (b) the consumption of Feta and the perception of consumers inside and outside Greece; (c) the existence of national legislation specifically relating to Feta; and, (d) the way the name was used under Community legislation.
} 
precisely the point where one of the biggest challenges for producers arises. After all, in most cases, it is up to the producers to prove that their respective names have not become generic. Also, this is a rather expensive challenge. ${ }^{50}$

Apart from the nuances, which might differentiate one country's approach, there are two predominant criteria used in the interpretation process. It is safe to say that the EU and the US are significant reference points in this regard. While the EU adopts a subjective criterion, the US is in favour of an objective criterion.

If we go back to the Grana Padano case, it provides us with a detailed summary of the criteria adopted to assess genericness. ${ }^{51}$ In conclusion, we find that, in the view of the Court, when determining if a term has become generic (as applied in the Grana Padano case), it is essential to look at:

the quantity of goods which bear the name in question and are produced using non-traditional methods as against the quantity of goods produced using traditional methods, [and] the market share held by goods bearing the name in question which were produced using non-traditional methods as against the market share held by goods produced using traditional methods.

This understanding makes it evident that the European approach to genericness is mostly based on the common European perception of the given name, ${ }^{52}$ as previously shown in the Feta cases. Back then, in the second Feta case, the Advocate General ${ }^{53}$ sought the reason why names describing a product that has an attachment to its origin might become generic due to widespread use of the term. Those motives are diverse and relate to: (a) the competitor's behaviour (whether there is or is not an intention of free-riding); (b) good faith in the name's usage; and (c) inaction on the part of those legitimated to make use of the GI term and of the consumers and authorities. ${ }^{54}$

From the EU perspective, unlike in the case of trademarks where it is expected that the intellectual property owner actively protects its sign, in the case of GIs the connection between legal protection and the producers' actions is much less intense.

\footnotetext{
50 O'Connor and Company (2006).

51 Case T-291/03 - Consorzio per la tutela del formaggio Grana Padano v OHMI - Biraghi (GRANA BIRAGHI), Judgment of 2007.

52 For more on the majoritarian approach in general in EU case law, see Maduro (1998). See also Proposal for a Council Decision drawing up a non-exhaustive, indicative list of the names of agricultural products and foodstuffs regarded as being generic, as provided for in Article 3(3) of Council Regulation (EEC) No 2081/92.

53 Opinion of Mr Advocate General Ruiz-Jarabo Colomer delivered on 10 May 2005. Federal Republic of Germany (C-465/02) and Kingdom of Denmark (C-466/02) v Commission of the European Communities, Judgment of 10 May 2005, paras. 134-135.

54 Rørdam (2013), pp. 182-183, when talking about the intention and coverage of the EU Regulation, calls attention to the fact that "the English version only refers to passivity by consumers and authorities, but that the French, Danish, German and Swedish versions also refer to passivity among other stakeholders (those affected) (des intéressés, de berettigede, der Betroffenen and de berördas), which must indicate the traders/businesses producing the product in the original way in the geographical area".
} 
Besides that, the regulations in force expressly repeal the possibility of a protected name becoming generic. ${ }^{55}$

Back to the Grana case before OHIM, the Board of Appeal declared that determining whether a term for which protection is requested constitutes a generic name or deserves protection depends on various factors. In this regard, the ECJ case law has established that a detailed analysis needs to consider economic, technical, historical, cultural and social interactions, and evidence, against the law in force ${ }^{56}$ (which is evolving). The analysis should also be based on the average consumer perception about the name and data from the market, not only in the country of origin but also in other Member States. ${ }^{57}$

Switching from the EU to the US perspective, we are before a diverse system, which is not sui generis ${ }^{58}$ and where legal protection of GIs is acquired through the trademark system. In this sense, a GI can be protected in the US either as a trademark, ${ }^{59}$ a certification mark $^{60}$ or a collective mark. ${ }^{61}$

Therefore, the US approach is the opposite of the European principles. Moreover, the US has always believed that many European GIs are generic in the US. When used by US producers, a term such as Champagne would not confuse consumers regarding the real origin of the product. Consequently, the US has always sought to ensure that national producers have the right to use those (generic - as they claim) GI terms as they find appropriate. ${ }^{62}$

\footnotetext{
55 This assertion can, of course, be challenged, as in Parmesan II the Court pointed out that "Germany has failed to prove that Feta had become generic". Also, none of the legal texts on PGI/PDOs address the rationale behind and the paradoxes in Art. 13(2).

56 The Court of First Instance considered that the Italian legal context and the practices adopted in the country towards Grana Padano cheese were another indication that the name was not generic.

${ }^{57}$ In the Grana case, the Court of First Instance then found that the Board of Appeal had not applied those criteria identified in the case law. At that time, there was no consumer survey, no legal-expert consultation, and no market-information request. Therefore, the decision of the Board of Appeal was not able to establish the genericness of the name.

58 There is a sui generis system for wines.

59 Terms or signs that had become generic cannot be registered as a trademark if they are descriptive or misdescriptive of the produced goods' origin. However, if a geographic sign is used in such a way as to identify the source of the goods/services and over time consumers start to recognise it as identifying a particular company or manufacturer, or group of producers, the geographic sign no longer describes only where the goods/services come from, it also describes the "source" of the goods/services. At that point, the sign has "secondary meaning" or "acquired distinctiveness". USPTO, Geographical Indication Protection in the United States. See also 15 United States Code Section 1052.

${ }^{60}$ For geographical names that would likely be considered primarily geographically descriptive and, consequently, unregistrable as trademarks or collective marks without having proved acquired distinctiveness in the US, the system allows them to be registered as certification marks.

${ }^{61}$ Under collective marks in the US, there are two types, which are: (a) collective trademarks or collective service marks, and (b) collective membership marks. The distinction between the two kinds was made by the USPTO administrative tribunal, the Trademark Trial and Appeal Board (TTAB) in Aloe Creme Laboratories, Inc. v American Society for Aesthetic Plastic Surgery, Inc., 192 USPQ 170, 173, Judgment of 1976.
}

${ }^{62}$ Calboli (2006), p. 182. 
American law is based exclusively on the opinion of the consumer and the relevant trade sector. It does not consider the right holder's behaviour and, once a term has become generic, ${ }^{63}$ anyone can freely use it. ${ }^{64}$

Hence, even cases with a positive outcome for the European GIs have decisions based on the same criteria. That is the case for Cognac. ${ }^{65}$ The USPTO Trademark Trial and Appeal Board (TTAB) held that Cognac was protected as a common-law (unregistered) regional certification mark in the United States, rather than being a generic term. The reasoning for the decision is that because US consumers primarily understand Cognac as a designation to refer to brandy originating in the Cognac region of France and they do not see Cognac as any brandy produced anywhere, the term was not declared generic. ${ }^{66}$

The US producers usually consider that the EU GI protection system works as if it were entitled to monopolise common or traditional names that those producers find to be generic, such as Feta, Parmesan and Provolone to name a few kinds of cheese. By doing so, the US producers claim they face an unfair limitation in marketing their products with those common names.

Nevertheless, the criteria on which the US bases its genericness assessment are then more objective. There is nothing like the consumer survey to collect their thoughts, for instance. "This consumer understanding is based on the following criteria: dictionaries, newspapers, websites, trade usage, standard rules (like the Codex Alimentarius), and use of the term with imported goods from a place different from the original location (the GI origin)." 67

From these two different approaches, which one is better? Why? Will the bilateral agreements change the way the EU assesses genericness? Or will they change the way the US assesses genericness?

There is no definitive answer if we consider only the objective criteria - the opinion and behaviour of the trade and the relevant consumer - without balancing the subjective criterion (the owner of the right's behaviour) as that would be expropriation of a private property right.

It is not irrelevant to give more weight to objective criteria (for example, consumer understanding, including consumer surveys, trade usage, dictionary definitions, expert opinions, magazines, newspapers, websites, market conditions and legislative or administrative rules) or subjective criteria (the behaviour or inaction of the owners of the right). Furthermore, the balance is between a favourable trade perspective or a subjective industrial property right perspective. This subjective perspective is based not only on the protection of a fundamental property right, but also on a presumption of the industrial property's validity. Thus,

\footnotetext{
63 "A geographic term or sign is considered 'generic' when it is so widely used that consumers view it as designating a category of all of the goods/services of the same type, rather than as a geographic origin", USPTO, Geographical Indication Protection in the United States.

6415 United States Code Section 1064.

65 Cognac is then protected in the US by common law, under which principles geographical indications are also protected through common law trademark law without being registered by the USPTO.

66 Institut National Des Appellations v Brown-Forman Corp, 47 USPQ2d 1875, 1884, Judgment of 1998.

67 See Ribeiro de Almeida (2020).
} 
it will be necessary for those that believe that the DO or GI has become generic to reverse this presumption in order to annul the property right.

On the other hand, it is possible to extract a principle from the EU legal regime on trademarks. The subjective criteria are essential to consider a trademark as a generic term ${ }^{68}$ pursuant to the rules in force. From these rules, we may extract a principle common to all distinctive trade signs, including DOs and GIs.

This also means that we need to make the industrial property right owner liable for his right becoming generic, and consider his actions or inactions. The right owner might use the term as generic or the relevant public might use the term as generic, and the right owner might do nothing to prevent that, even if he has the legal means to do so. ${ }^{69}$ Only with the ascription of liability to the right owner, can we consider that the term has become generic. Usually, the owner's behaviour is due to a lack of action when the term protected as an industrial property right starts to be used as a generic term by the relevant public (consumers of the concerned goods and trade opinion). Of course, genericness can only be recognised when, with the ascription of liability, ${ }^{70}$ the term complies with its legal functions (geographic, qualitative, or ideographic) according to the relevant public (consumers of the concerned goods and trade opinion). If a non-negligible part of the relevant public still makes any of those links (geographic, qualitative, or ideographic), the sign has not lost its significance as a DO or a GI and is not generic.

\section{Survival and Revival of Generic Terms}

As we underlined before, the qualification of a DO or GI as a generic term demands the breakdown of both the geographic-qualitative link (a link of truth) and the ideographic connection (an unprecedented power) with an individual geographical origin. However, it is possible, by law, to maintain the protection of the industrial property right, even if the geographical name is already generic, according to the criteria that we have indicated, as it is possible for a geographical name that is generic to acquire distinctiveness (always by law but using different tools).

There might be a strong product connection with a particular region (the product is unique in its characteristics and or quality), plus the fact that usually a DO or a GI is composed of the geographical name of that region. The relevant consumer and the

\footnotetext{
68 Case C-409/12 - Backaldrin Österreich The Kornspitz Company, Judgment of 2014, para. 32, points out that: "it must be borne in mind that, by balancing the interests of the proprietor of a trade mark against those of his competitors in the availability of signs, the European Union legislature, in adopting Article 12(2)(a) of that directive, considered that the loss of that mark's distinctive character can be relied on against the proprietor thereof only where that loss is due to his action or inaction".

69 Inaction by the owners of the right, without due cause, will create trust and good faith in the other competitors (they will understand the inaction by the owners of the right as renouncement or abandonment - the dynamics of trade do not tolerate abstentions). This trust and good faith will imply that any action taken afterwards by the owners of the right would be under the institution of abuse of right and the modality of suppressio. However, if the right owners use it as a generic term, any action taken afterwards to protect the right would be under the prohibition of venire contra factum proprium. For more details, see Ribeiro de Almeida (2015).

${ }^{70}$ On this liability (Zurechenbarkeit), see Fezer (2009), p. 2076.
} 
interested trade's usual practice might be to use the DO or GI as the product's name because of its uniqueness. ${ }^{71}$ These facts lead to a considerable risk of genericness for those industrial property rights. ${ }^{72}$ Such a risk explains the ban on genericness in some national legal systems, ${ }^{73}$ European Union law $^{74}$ and some international agreements. ${ }^{75}$ This means that the lack of distinctiveness (and, consequently, the destruction of the object of the subjective right) does not imply the death of the industrial property right. ${ }^{76}$ Death is legally forbidden.

There are geographical terms that are generic and cannot be protected as GIs or DOs; the rules indicated above state that a term that has been protected as a GI or DO cannot become generic. However, the legal system cannot allow the monopolisation of generic terms ${ }^{77}$ or terms that have become generic in the market (despite the rules in force). At the EU level, we must underline three points. Firstly, the possibility of a DO or GI becoming generic in its country of origin is not foreseen and, for that reason, the registration should be cancelled ${ }^{78}$ (this is because we have an exclusive and unique system at the EU level). Secondly, there are no geographical terms that, a priori, are not generic and cannot become generic ${ }^{79}$ (this is only theoretical perpetuity ${ }^{80}$ ). Thirdly, the use, de facto, of a protected DO or GI

\footnotetext{
71 If we want a washing machine, there are several options in the market (sometimes those washing machines are identical even if they come from different companies with different trademarks), but if we want Champagne, Port or Roquefort, the product is unique (there are several sparkling wines, fortified wines and blue cheeses in the market, but they are different, namely in their geographical origin, quality and characteristics).

72 This risk explains the forbiddance of translations, the indication of true origin of the products or services and the use of expressions such as style, type, method, as produced in, imitation or similar (besides, of course, usurpations, misuse, imitations or evocations, or use as an ingredient). It is the risk of genericness that is the ground for these prohibitions.

73 In France, for example, the Code rural et de la pêche maritime establishes the following (Art. L. 643-1): "L'appellation d'origine ne peut jamais être considérée comme présentant un caractère générique et tomber dans le domaine public".

74 See Art. 13(2) Regulation (EU) No 1151/2012, Art. 103(3) Regulation (EU) No 1308/2013, Art. 21(3) Regulation (EU) 2019/787, and Art. 20(3) Regulation (EU) 251/2014.

75 See Art. 6 Lisbon Agreement for the Protection of Appellations of Origin and their International Registration (as revised at Stockholm on 14 July 1967, and as amended on 28 September 1979), Art. 12 Geneva Act of the Lisbon Agreement on Appellations of Origin and Geographical Indications, and Art. 4 Madrid Agreement for the Repression of False or Deceptive Indications of Source on Goods (1891).

76 About the possibility or impossibility of genericness in other intellectual property rights, see Cohen Jehoram (2007), p. 205 et seq.

77 See Glaus (1996), p. 46.

78 As provided by Art. 6 Lisbon Agreement: "as long as it is protected as an appellation of origin in the country of origin”. In this respect, see Agra (2001), p. 212.

79 See Denis (1995), p. 32.

${ }^{80}$ Mikorey (2001), p. 105.
} 
as a generic term would be considered an infringement of the specification and, consequently, a ground for cancellation of the registration. ${ }^{81,82}$

At the international level, the Madrid Agreement, indicated above, has a minimal scope (only wine products - Art. 4) and does not forbid the use of terms such as like, type, and similar ones, as well as translations or the accurate indication of the origin. ${ }^{83}$ This means that the Madrid Agreement is weak on protection against genericness. The Lisbon Agreement was a step forward. However, if Art. 6 seems very clear: "An appellation which has been granted protection in one of the countries of the Special Union according to the procedure under Article 5 cannot, in that country, be deemed to have become generic, as long as it is protected as an appellation of origin in the country of origin". This means that, once the appellation of origin is registered internationally, it cannot be considered a generic term in the jurisdiction of one of the members of the Special Union (if this member has not refused protection of that term as an appellation of origin), if it is not considered generic (or loses protection for any other reason) in the country of origin. Except for the country of origin's jurisdictions, the other jurisdictions could not consider the term generic. ${ }^{84}$ The Geneva Act has changed the wording of the previous Art. 6 , now Art. 12: "Subject to the provisions of this Act, registered appellations of origin and registered geographical indications cannot be considered to have become generic [2] in a Contracting Party". Besides, there is an agreement that clarifies:

For the purposes of this Act, it is understood that Article 12 is without prejudice to the application of the provisions of this Act concerning prior use, as, prior to international registration, the denomination or indication constituting the appellation of origin or geographical indication may already, in whole or in part, be generic in a Contracting Party other than the Contracting Party of origin, for example, because the denomination or indication, or part of it, is identical with a term customary in common language as the common

\footnotetext{
81 See Art. 54(1)(a) Regulation (EU) No 1151/2012, Arts. 19, 20 and 21 Commission Delegated Regulation (EU) 2019/33 of 17 October 2018 supplementing Regulation (EU) No 1308/2013 of the European Parliament and of the Council as regards applications for protection of designations of origin, geographical indications and traditional terms in the wine sector, the objection procedure, restrictions of use, amendments to product specifications, cancellation of protection, and labelling and presentation, Art. 32(1)(a) Regulation (EU) 2019/787, and Art. 25 Regulation (EU) 251/2014.

${ }^{82}$ In this sense, see Mikorey (2001), p. 105; Agra (2001), p. 212.

83 See Conrad (1996), p. 25; Bretscher (1931), p. 111; Knaak (1995), p. 643. Some authors even consider (contrary to our opinion) that Art. 4 of the indicated Madrid Agreement does not cover designations of origin. In this respect, see, for instance, Ladas (1975), p. 1591.

${ }^{84}$ About this interpretation, see Lackert (1998), p. 24; and Heath (2004), p. 114, where it is said: "esattamente il principio di incontestabilità che conferisce all'Accordo di Lisbona il sua reale significato ed assicura che la protezione sia effettivamente omogenea in tutti gli stati membri e non sia fatta a pezzi dalle corti dopo che il periodo di opposizione di un anno sia trascorso". However, several national jurisdictions have considered that they may qualify an appellation of origin as a generic term and deny the international protection conferred by the Lisbon Agreement. See Ribeiro de Almeida (2010), pp. 215-216.
} 
name of a good or service in such Contracting Party, or is identical with the customary name of a grape variety in such Contracting Party. ${ }^{85}$

Therefore, besides the possible refusal effects of an international registration in its territory (Art. 15) and the power to invalidate the effects, in part or whole, of an international registration (with the condition of giving the beneficiaries an opportunity to defend their rights - see Art. 19), a contracting party can always claim that an indication that constitutes an appellation of origin or a geographical indication is a generic term. ${ }^{86}$ Accordingly, if the name was already a generic term in a contracting party before the registration (other than the contracting party of origin), the international registration will not affect those generic uses. It is always possible for a contracting party to invalidate the effects of an international registration on the ground that the term became generic after the international registration (Art. 19 does not preclude this possibility nor does Art. 12 safeguard it).

The prohibition of genericness in some national legal systems and international agreements ${ }^{87}$ does not prevent the name from becoming, de facto, generic and losing its economic value. Its collective nature and the protection of national, regional values are insufficient grounds to preclude genericness. This position of some legal systems would allow the owners of the DO or GI to take action against those that use the geographical name as a generic term; however, it must be weighed if the owners of the right have not also used the name as a generic term or, at least, have not taken the necessary measures against the generic uses (and had the legal means to do so). In such cases, the subsequent invocation of their rights (ius prohibendi) over the name would be considered an abuse of their rights (based not only on the principle of good faith and trust or fiducia generated by those that use the name as generic but also on the clause of venire contra factum proprium).

It is also possible for the resurrection or revival of a DO or GI that is considered generic (Rückentwicklung ${ }^{88}$ ). Recovering the original significance means the rebirth of the geographical and qualitative connection (the DO and GI legal functions). This renaissance is not easy (in fact, it is very difficult ${ }^{89}$ ), and demands substantial promotion and the modification of the dominant conception in the trade and the relevant public. In these circles, a renaissance should occur and be a precondition for reinstating the industrial property right. However, this has not been the primary mechanism of resurrection. Through bilateral agreements and in trade-off

\footnotetext{
85 This safeguard clause is similar to the one established in Art. 24(6) TRIPS Agreement. Interestingly, prior uses are safeguarded by Art. 24(4) and earlier trademarks in Art. 24(5).

${ }^{86}$ It is useful to underline that, according to the above statement, there is equivalence between a generic term and a term customary in common language, including a common name or a customary name. The criterion behind this language is objective, namely common language and not the behaviour of the owner of the right.

${ }^{87}$ Some doctrine applies this reasoning to collective and certification marks. See, for instance, Trigona (2002), p. 76.

88 See Michel (1995), p. 44; Sinanioti (1987), p. 45 et seq.; Glaus (1996), p. 51.

89 There are few examples of trademarks that have acquired a distinctive function after having become generic. McCarthy (1996), pp. 12-68 brings two examples: "Singer" and "Goodyear". About this problem, see also Beier (1980), p. 23; and Hoeth (1980), p. 82, who provides the example of "Cognac" in Holland.
} 
negotiations several terms have acquired protection as DOs or GIs; otherwise, and most probably, it would have been challenging to recover the original significance and distinctiveness.

The restoration of the original significance has occurred in the field of international agreements. This renaissance of DOs or GIs through international agreements has no parallel in other industrial property rights. ${ }^{90}$ There are several $^{2}$ examples; we will refer to just some of them. ${ }^{91}$ In the UK case, Vine Products Ltd. v. MacKenzie \& Co. Ltd (1969), Cross J. considered that the Spanish producers of sherry had not taken timely action against the use of expressions such as British Sherry, South African Sherry, English Sherry, Australian Sherry, Irish Sherry, and Cyprus Sherry, and so they could no longer act. When Spain became a member of the EU, it was negotiated that Sherry would be reserved for the Spanish producers from Jerez de la Frontera. ${ }^{92}$ Many examples can be seen in the bilateral agreements concluded by the EU with third countries, such as Australia, South Africa, and Chile, where after a phasing-out the European DO and GI are protected in those countries even if at the time of the negotiations they were considered generic or common terms. It should be taken into consideration that in several of those third countries, the European GI and DO were not legally (namely by a jurisdiction) qualified as generic terms. In several of them, there were no legal means in force for the owners of those industrial property rights to act because those third countries did not recognise DOs or GIs as industrial property rights. In any case, an artificial restoration of a generic term will hurt the basic principles of distinctiveness and trade freedom and competition. ${ }^{93}$

The rebirth of a GI or DO, or even a trademark, is very difficult ${ }^{94}$ and should obey the same genericness criteria. ${ }^{95}$ The renaissance of the significance (distinctiveness) of the geographical name as a DO or GI will demand strong efforts from the owners through publicity, promotion, re-education of the consumer, information, and constant vigilance against any imitation or usurpation, in order to change

\footnotetext{
90 The legal nature of those rights and the confusion between collective, public, and national or European economic interests explain this type of protection and disregard the fact that we are dealing with competition tools in a very competitive market and that DO and GI are in the hands of some.

91 We will not consider the peace treaties of World War I because they were concluded in exceptional times. On those treaties and the protection provided for geographical names, see Borssat (1923), pp. 49-50; Plaisant and Fernand-Jacq (1921), p. 313 et seq.; Ladas (1975), p. 750 et seq.; Tilmann (1976), p. 133 et seq.; Roubier (1954), p. 809. Another interesting and recent case is the protection of the DO Cognac in Brazil, see Soares (2000), p. 25 et seq. For the Brazilian legislation on GIs, see Carls (2020).

92 About this case, see Dawson (2000), pp. 603-604; Dawson (1988), p. 67 et seq.; Ricketson (1994), p. 870; Gargallo (2002), p. 198 et seq.

93 To be precise, in several of those third countries the EU DOs and GIs were not generic, but common names and, in almost all of the cases, there were references to the true origin of the product, which means that the term was not generic. The process of genericness was stopped in time (using the power of the law). On this problem, see van Caenegem (2004), p. 179. On the Versailles Treaty forbidding Germany from using the designations Cognac and Champagne, see Sinanioti (1987), p. 47.

94 See Dickertmann (2001), pp. 32-33; Omsels (2007), p. 176 et seq.

95 See Tilmann (1976), p. 369; and Omsels (2007), p. 176, who says: "Die Rechtsprechung fordert dafür in gleicher Weise wie für die Umwandlung einer originären Gattungsbezeichnung in eine geografische Herkunftsangabe, dass der überwiegende Teil des angesprochenen Verkehrs aus der (Gattungs-) Bezeichnung wieder auf die örtliche Herkunft schließt".
} 
the dominant comprehension of the name by the relevant consumer and in the trade (but, especially, in the sphere of the relevant consumer). ${ }^{96}$ We can look at this problem from another angle: can a generic term acquire a secondary meaning? Some doctrine considers that a generic term cannot benefit from the mechanism of secondary meaning. ${ }^{97}$ However, in our opinion, it is vital to distinguish generic terms from common names (for example wine is a generic term; sparkling is a descriptive term, and Champagne is a common name in some countries). ${ }^{98}$ This explains why the same doctrine also says that "some terms which were originally geographically generic can lose their generic significance and become valid marks by reason of exclusive use of a single seller who acquires secondary meaning. This was the case with BUDWEISER beer". 99

To finalise this point, it is essential - as we have done in this text - to use the qualification generic in its precise and correct way, meaning the product's name. This means that when we see (for example on the label) references or allusions to the true origin of the product (explicitly or using images, flags, or any other indirect references), or words like kind and type, for instance, this means that the term is not yet generic. It happens that the user, who does not have the right to use the DO or GI, takes advantage of the reputation or prestige of the DO or GI in order to sell his products more easily, by evoking in the mind of the relevant group of consumers designations that say something or appeal to them. ${ }^{100}$ The risk of genericness mainly occurs in the case of a prestigious, notorious, or reputed DO or GI. The search for references that connect the product, in the mind of the relevant group of consumers, with the correct origin (opportunistic labelling) means that the geographical name has not lost its significance. This means that the DO or GI has not become generic, there is still a geographic connection with its origin (the geographical link has not yet been destroyed or lost). The name is not generic, and a significant part of the relevant public still makes that link (the legal functions of the DO or GI have not broken down).

\section{Conclusions}

Considering the legal functions of DOs and GIs (geographical origin, quality, and publicity), we can analyse the possible genericness of industrial property rights. It is necessary to break down the geographic and qualitative link, and the ideographic

\footnotetext{
96 See Sinanioti (1987), p. 46; and Dawson (2000), p. 604, who says: "The process of rollback of generic terms is the most difficult issue surrounding the legal protection of geographical indications".

97 McCarthy (1996), pp. 12-89, writes: "Once determined to be generic, no amount of purported evidence of secondary meaning can serve to give legal protection to the generic term".

98 See Novoa (1990), p. 76; Sordelli (1979), pp. 226 et seq., 228 et seq.

99 McCarthy (1996), pp. 14-35.

100 Taking into consideration the Feta case, O'Connor and Kireeva (2003), p. 117, say that: "Surely by naming the cheese 'Feta', rather than white cheese in brine, Denmark and other 'Feta' producing countries sought to gain something. (...) It is the producers' best commercial interest to give the product a name which resonates or has consumer meaning. Otherwise, the producer will use a different name. The producer makes an evaluation to determine which name will result in the highest level of sales."
} 
link with the region. If the sign no longer identifies a product from a particular region and with a certain quality or characteristics, the ideographic link has been lost because of the DO or GI's reputation or distinctive power. The relevant public $^{101}$ ceases to make any of those links (geographic, qualitative, or ideographic) when buying the product with the sign. If a non-negligible part of the relevant public still makes any of those links, the sign has not lost its significance as a DO or a GI (the sign is not generic). This also means that our position is based on objective criteria $^{102}$ favourable to freedom of competition. However, we are in the arena of industrial property rights, and property is a fundamental right. Besides, there is a presumption of validity of the industrial property right. Thus, it will be necessary for those that claim that the DO or GI has become generic to reverse this presumption in a way that will annul the property right.

On the other hand, to reverse this presumption, it is necessary to make the owner of the industrial property right liable for action or inaction. That is the EU legal position concerning the leading distinctive sign in trade (trademark). From this legal option, we may extract a principle: the subjective criterion is essential. Without that ascription of liability to the industrial property right owner, it is impossible to consider a term that is protected as an industrial property right to be generic.

It is then necessary to interpret the subjective assumption regarding the essential functions of DOs and GIs. The subjective assumption is a requirement for genericness (since genericness must be a consequence of the activity or inactivity of the owners), understood in objective terms (with respect to the essential function of the right) and not subordinate to the will (animus derelinquendi) of the owners of the right. ${ }^{103}$ Moreover, it is a requirement precisely because the right holder actively contributed to this genericness or did nothing to prevent it (violating the honeste vivere, exercising your faculties or rights correctly and not abusing your freedom, to act or not to act, in the legal field). The problem will always be the following: whether the holders reacted in time and in a way that prevented genericness and thus avoiding the extinction of the right because the object of the right was not destroyed; or whether the holders reacted too late or in an ineffective way, so that the object of the right was already destroyed, and the consequence will be the extinction of the right (what is at stake in determining whether the efforts of the right holders have raised awareness among the target public).

It seems that, considering the most recent international agreements, we are moving to a US perspective. However, if we want to maintain the European legacy especially concerning GI protection - and the competitiveness of EU products, we must follow a subjective perspective on our legacy of protecting fundamental rights and human rights.

\footnotetext{
101 Matthiolius (1929), p. 20, writes: "Maßgebend für die Beurteilung der Frage, ob die Entwicklung der Gattungsbezeichnung abgeschlossen ist, ist die Verkehrsauffassung".

102 Certainly, if the owners of the DO or GI stay inactive or inert in the face of undue uses of their industrial property right, that will favour genericness.

103 Genericness does not require fault ("Verschulden" according to $\$ 276$ of the BGB) of the holder of the right; an objective ascription ("objective Zurechenbarkeit") of the holder of the right is enough. See Fezer (2009), p. 2076.
} 
We may finalise with Jean-Jacques Rousseau, Émile ou de l'Éducation, Livre premier, "Tout est bien sortant des mains de l'Auteur des choses; tout dégénère entre les mains de l'homme".

Funding Open Access funding enabled and organized by Projekt DEAL.

Open Access This article is licensed under a Creative Commons Attribution 4.0 International License, which permits use, sharing, adaptation, distribution and reproduction in any medium or format, as long as you give appropriate credit to the original author(s) and the source, provide a link to the Creative Commons licence, and indicate if changes were made. The images or other third party material in this article are included in the article's Creative Commons licence, unless indicated otherwise in a credit line to the material. If material is not included in the article's Creative Commons licence and your intended use is not permitted by statutory regulation or exceeds the permitted use, you will need to obtain permission directly from the copyright holder. To view a copy of this licence, visit http:// creativecommons.org/licenses/by/4.0/.

\section{References}

Agra MJB (2001) Las denominaciones de origen. Marcial Pons, Madrid

Beier F-K (1980) The protection of indications of geographical origin in the Federal Republic of Germany. In: Cohen Jehoram H (ed) Protection of geographic denominations of goods and services. Sijthoff \& Noordhoff, Alphen a.d. Rijn; Germantown, pp 183-206

de Borssat X (1923) Législation et jurisprudence sur les fraudes et falsifications et les appellations d'origine. Imprimerie champenoise, Langres

Bretscher J (1931) Der Schutz geographischer Herkunftsbezeichnungen. Universität Zurich, Zurich

Briceno Moraia L (2000) Ancora sul marchio Aspirina. Riv di Dirit Industriale II

Byrne J (2006) Feta cheese and pork pies: PDOs and PGIs! J Brand Manag 13:363-367

Calboli I (2006) Expanding the protection of geographical indications of origin under TRIPS: old debate or new opportunity. Marquette Intellect Prop Law Rev 10:181-203

Carls S (2020) Brazilian GIs landscape: from the TRIPS commitments to the real world, what was achieved, what is yet to be faced? GRUR Int. https://doi.org/10.1093/grurint/ikaa103

Cohen Jehoram H (2007) The Dutch Supreme Court recognises "dilution of copyright" by degeneration of a copyright design into unprotected style. The Flying Dutchman: all sails, no anchor II. EIPR 205-208

Conrad A (1996) The protection of geographical indications in the TRIPs agreement. Trademark Report 86

Correa C, Correa CM (2007) Trade related aspects of intellectual property rights: a commentary on the TRIPS agreement. Oxford University Press, Oxford

Dawson N (1988) Certification trade marks: law and practice. Intellectual Property Publishing, London

Dawson N (2000) Locating geographical indications: perspectives from English law. Trademark Report 90

Denis D (1995) Appellation d'origine et indication de provenance. Dalloz, Paris

Dickertmann WC (2001) Die geographische Herkunftsangabe zwischen gewerblichem Rechtsschutz und Wettbewerbsrecht: der Einfluss des europäischen Rechts auf den Schutz der geographischen Herkunftsangabe. Nomos, Baden-Baden

Die geographische Herkunftsangabe: Tatsachen, Rechtsschutz und rechtspolitische Entwicklung im Inland, im Ausland und im internationalen Bereich. Beck, Munich

Fezer K-H (2009) Markenrecht. C.H. Beck, Munich

Fletcher AL (2013) Separating descriptive sheep from generic goats. Trademark Report 103

Frassi PAE (2013) Riflessioni sul fenomeno della volgarizzazione del marchio. In: Frassi PAE (ed) Scritti scelti di diritto industriale e diritto d'autore. Giuffrè, Milan, pp 21-38

Gangjee DS (2012) Relocating the law of geographical indications. Cambridge University Press, Cambridge 
Gangjee DS (2016) Genericide: the death of a geographical indication? In: Gangjee DS (ed) Research handbook on intellectual property and geographical indications. Edward Elgar Publishing, Cheltenham

Gargallo MMM (2002) La protección jurídica de las denominaciónes de origen en los derechos español y comunitario. Marcial Pons, Madrid

Gervais DJ (2003) The TRIPS Agreement: drafting history and analysis. Sweet \& Maxwell, London

Ghidini G, Cavani G (2014) Lezioni di diritto industriale. Proprietà industriale, intellettuale e concorrenza. Giuffrè, Milan

Glaus U (1996) Die geographische Herkunftsangabe als Kennzeichen. Helbing \& Lichtenhahn, Basel

Heath C (2004) Il caso Budweiser. Riv di Dirit Ind 53:77-129

Hoeth W (1980) Protection of geographical denominations in the Netherlands. In: Cohen Jehoram H (ed) Protection of geographic denominations of goods and services. Sijthoff \& Noordhoff, Alphen a.d. Rijn, Germantown, pp 75-88

Holland D, Pope H (2004) EU food law and policy. Kluwer Law International, The Hague

Jokuti A (2009) Where is the what if the what is why? A rough guide to the maze of geographical indications. Eur Intellect Prop Rev No 3

Knaak R (1995) Der Schutz geographischer Angaben nach dem TRIPS-Abkommen. GRUR Int 8:642-655

Knaak R (2015) Geographical indications and their relationship with trade marks in EU law. IIC Int Rev Intellect Prop Compet Law 46:843-867. https://doi.org/10.1007/s40319-015-0393-1

Kur A, Cocks S (2007) Nothing but a GI thing: geographical indications under EU law. Fordham Intellect Prop Media Entertain Law J 17

Lackert CW (1998) Geographical indications: what does the WTO TRIPs agreement require? Informa Law

Ladas SP (1975) Patents, trademarks, and related rights: national and international protection. Harvard University Press

Le droit de la propriété industrielle: partie spećiale. Les créations nouvelles. Les signes distinctifs. Éditions du Recueil Sirey, Paris

Liuzzo L (1994) Grounds for loss of trade mark rights in Italy: transformation into a generic term and revocation. Springer

MacMaoláin C (2007) EU food law: protecting consumers and health in a common market. Bloomsbury Publishing

Maduro MP (1998) We the court: The European Court of Justice and the European Economic Constitution: a critical reading of Article 30 of the EC Treaty. Hart Publishing

Massimo FMS, Fransozi M (2014) Diritto industriale italiano, tomo primo, diritto sostanziale. Cedam

Matthiolius K (1929) Der Rechtsschutz geographischer Herkunftsangaben. Munich/Berlin/Leipzig

McCarthy JT (1996) McCarthy on trademarks and unfair competition. West Group

McManis CR (2000) Intellectual property and unfair competition in a nutshell. West Group

Michel WF (1995) Der Schutz geographischer Herkunftsangaben durch das Markenrecht und certification marks. Berlin-Verlag Spitz

Mikorey C (2001) Der Schutz von geographischen Angaben und Ursprungsbezeichnungen für Agrarerzeugnisse und Lebensmittel in der Europäischen Gemeinschaft nach der Verordnung 2081/92. Lang, Frankfurt

Novoa CF (1990) Derecho de marcas. Editorial Montecorvo, Madrid

Omsels HJ (2007) Geografische Herkunftsangaben. C. Heymanns, Cologne/Munich

O'Connor and Company (2006) Geographical indications and TRIPs: 10 years later...a roadmap for EU GI holders to get protection in other WTO Members: Part I protection of geographical indications in 160 countries around the world. Insight Consulting

O'Connor B, Kireeva I (2003) What's in a name? The "feta" cheese saga. Int Trade Law Regul 110-120

Plaisant M, Fernand-Jacq M (1921) Traité des noms et appellations d'origine. Librairie Arthur Rousseau, Paris

Ribeiro de Almeida AF (2010) A autonomia jurídica da denominação de origem: uma perspectiva transnacional. Uma garantia de qualidade, Coimbra Editora

Ribeiro de Almeida A (2020) Geographical indications versus trade marks and generic terms: the USChina Agreement. IIC Int Rev Intellect Prop Compet Law 51:277-281. https://doi.org/10.1007/ s40319-020-00923-0 
Ribeiro de Almeida A (2015) Degenerescência da marca. Destruição da coisa. Extinção do direito. In: Estudos de Direito Intelectual em Homenagem ao Prof. Doutor José de Oliveira Ascensão. Almedina, Coimbra, Portugal, pp 637-657

Ricketson S (1994) Intellectual property: cases, materials, and commentary. Butterworths, Sydney

Rørdam MO (2013) EU law on food naming: the prohibition against misleading names in an internal market context. PhD School of Economics and Management

Sinanioti A (1987) Der Schutz geographischer Herkunftsangaben und Ursprungsbezeichnungen. VVF, Munich

Soares JCT (2000) Cognac - denominação de origem vs. conhaque - nome comum. Rev da Assoc Bras da Propr Intelect II:25-27

Sordelli L (1979) Marchio e "secondary meaning." Giuffrè, Milan

Trigona R (2002) Il marchio, la ditta, l'insegna. Recenti sviluppi legislativi e giurisprudenziali (Enciclopedia). AbeBooks: 8813240082. CEDAM, Milan

Vanzetti A (2009) Note in tema di volgarizzazione del marchio (una riesumazione?). Riv di Dirit Ind 67:214-222

Vanzetti A (2013) Codice della proprietà industriale. Giuffrè, Milan

Vanzetti A, Di Cataldo V (2012) Manuale di diritto industriale. Giuffrè, Milan

van Caenegem W (2004) Registered GIs: intellectual property agricultural policy and international trade. ERA - Humanit Creat Arts

Publisher's Note Springer Nature remains neutral with regard to jurisdictional claims in published maps and institutional affiliations. 